\title{
How to Formulate Scientific Realism and Antirealism
}

Forthcoming in Journal for General Philosophy of Science

Seungbae Park

Ulsan National Institute of Science and Technology

The Republic of Korea

\begin{abstract}
The wider the gap between rivaling positions, the more there can be debates between rivaling interlocutors. The gap between the respective formulations of scientific realism and antirealism that invoke the Prussian conception of rationality is wider than the gap between the respective formulations of scientific realism and antirealism that invoke the English conception of rationality. Therefore, scientific realists and antirealists should choose the former over the latter as the framework of their debate.
\end{abstract}

\section{Keywords}

Scientific Antirealism, English Conception of Rationality, Prussian Conception of Rationality, Scientific Realism

\section{Introduction}

How should we formulate scientific realism and antirealism? This is an important question. Depending on how we answer it, there can be some or no debate between scientific realists and antirealists. This paper aims to show that the formulations of realism and antirealism that invoke the Prussian conception of rationality can generate debates, whereas the formulations of realism and antirealism that invoke the English conceptions of rationality cannot. The Prussian and English conceptions of rationality are developed by Bas van Fraassen (1989). Van Fraassen $(2007,2017)$ appeals to the English conception of rationality to confront challenges from Alan Musgrave (2017) and David Papineau (1996).

In Section 2, I explicate the English and Prussian conceptions of rationality and show how van Fraassen $(2007,2017)$ utilizes the English conception of rationality to respond to Papineau (1996) and Musgrave (2017). In Section 3, I present the formulations of realism and antirealism, respectively, that invoke the English conception of rationality as well as the formulations that invoke the Prussian conception of rationality. In Section 4, I argue that the gap between the formulations that invoke the Prussian conception of rationality is so wide that there can be debates between realists and antirealists, whereas the gap between the formulations that invoke the English conception of rationality is so narrow that there can be no debate between realists and antirealists. Consequently, realists and antirealists should choose the Prussian conception of rationality over the English conception of rationality. In Section 5, I reply to reviewers' objections.

\section{The English and Prussian Conceptions of Rationality}

In this section, I unpack the English and Prussian conceptions of rationality and then explore how van Fraassen makes use of the former to confront objections from Papineau and Musgrave.

The English conception of rationality holds that "what it is rational to believe includes anything that one is not rationally compelled to disbelieve" (van Fraassen, 1989: 171-172). In contrast, the Prussian conception of rationality holds that "what it is rational to believe is

\footnotetext{
${ }^{1}$ To disbelieve $p$ means neither to believe $\sim p$ nor to suspend judgment on $p$. It rather means not to believe $p$.
} 
exactly what one is rationally compelled to believe" (van Fraassen, 1989: 171). The English conception of rationality is inspired by the English legal tradition, according to which what is not explicitly prohibited is permitted. By contrast, the Prussian conception of rationality is inspired by the Prussian legal tradition, according to which what is not explicitly permitted is prohibited.

Van Fraassen (1989) contends that abduction does not rationally compel epistemic agents to believe $\mathrm{T}$, where $\mathrm{T}$ is a theory that offers the best explanations. Given that abduction is epistemically inert, the English conception of rationality implies that the disbelief of $\mathrm{T}$ is reasonable. He also claims that we do not have any argument that rationally compels us to disbelieve T. ${ }^{2}$ Given this, the English view of rationality implies that the belief of $\mathrm{T}$ is also reasonable. Thus, on van Fraassen's account, both the belief and the disbelief of T are reasonable. He chooses the disbelief of $\mathrm{T}$ over the belief of $\mathrm{T}$ on the grounds that the latter is "supererogatory" (van Fraassen, 2017: 102). This is van Fraassen's position.

What is required to refute van Fraassen's position? It is of no use for realists to prove that the belief of $\mathrm{T}$ is reasonable. After all, he already agrees with them that the belief of $\mathrm{T}$ is reasonable. So realists would rather have to prove that "it is unreasonable not to believe that H is true" (van Fraassen, 2017: 102). This contention is natural and obvious. As we have just seen above, under the condition that abduction is epistemically inert, the English conception of rationality implies that the disbelief of $\mathrm{T}$ is reasonable. This implication would be refuted if it were shown that the disbelief of $\mathrm{T}$ is unreasonable.

We are now ready to turn to the debate between van Fraassen and his critics. Papineau states, “According to van Fraassen's 'constructive empiricism' ... we ought never to believe in the truth of any theory which goes beyond the observable phenomena" (1996: 8). Van Fraassen accuses Papineau of committing the straw man fallacy, saying that "I do not advocate agnosticism about the unobservable, but claim that belief is supererogatory as far as science is concerned; you may if you like, but there is no need" (2007: 343, 2017: 99). Musgrave claims that "it is reasonable to believe that $\mathrm{H}$ is true" (2017: 80; emphasis in original). Van Fraassen retorts that "such a belief is reasonable enough, but supererogatory" (2017: 102). Thus, to argue that the belief of T is reasonable is not to weaken van Fraassen's position but rather to strengthen it.

\section{Different Formulations}

\subsection{The English Formulations}

In this section, I explicate English realism and English antirealism, show how English realists can make use of the English conception of rationality to defend their stance, and argue that English realists and antirealists ought not to criticize each other.

English realists believe $\mathrm{T}$ and assert that both the belief and the disbelief of $\mathrm{T}$ are reasonable. No philosopher has espoused this position before, although it can be inferred from the English antirealism that van Fraassen espouses. English antirealists disbelieve T but assert that both the belief and the disbelief of $\mathrm{T}$ are reasonable. As one can see, there are both a difference and a similarity between English realists and antirealists. The difference is that English realists believe T, while English antirealists disbelieve T. The similarity is that they commonly assert that both the belief and the disbelief of $\mathrm{T}$ are reasonable. The contents of English realism and antirealism can be made more explicit by the following imaginary dialogue between English realists and antirealists:

Antirealist: I disbelieve T. So my position is antirealism.

\footnotetext{
${ }^{2}$ Van Fraassen's claim conflicts with antirealists' contention that their arguments, such as the pessimistic induction and the problem of underdetermination, rationally compel us to disbelieve T (Park, 2019a: Section 3).
} 
Realist: I believe T. So my position is realism.

Antirealist: I disbelieve $\mathrm{T}$, but $\mathrm{I}$ concede that the belief of $\mathrm{T}$ is reasonable. My concession is predicated on the English conception of rationality.

Realist: I believe T, but I concede that the disbelief of T is reasonable. My concession is also predicated on the English conception of rationality.

Antirealist: You concede that the disbelief of $\mathrm{T}$ is reasonable. So your position might as well be called antirealism.

Realist: You concede that the belief of $\mathrm{T}$ is reasonable. So your position might as well be called realism.

Antirealist: I concede that the belief of $\mathrm{T}$ is reasonable. But I disbelieve $\mathrm{T}$. So my position is antirealism.

Realist: I concede that the disbelief of $\mathrm{T}$ is reasonable. But I believe T. So my position is realism.

Antirealist: I concede that your belief of $\mathrm{T}$ is reasonable. So I'll not criticize it. Why would I criticize a belief I take to be reasonable?

Realist: I concede that your disbelief of $\mathrm{T}$ is reasonable. So I'll not criticize it. Why would I criticize a disbelief I take to be reasonable?

Antirealist: If so, let me stick to my disbelief of T and go my own way. Have a nice day.

Realist: If so, let me stick to my belief of T and go my own way. Have a nice day.

This imaginary dialogue illustrates that the English conception of rationality can be used not only by English antirealists but also by English realists. The two parties, however, use it for different purposes. English realists use it to cling to the belief of T, whereas English antirealists use it to cling to the disbelief of T. It is equally rational for English realists to stick to the belief of $\mathrm{T}$ as it is for English antirealists to stick to the disbelief of T.

The foregoing dialogue also illustrates that English realists concede too much to English antirealists, saying that the English antirealists' disbelief of $\mathrm{T}$ is within the bounds of reason. So English realists ought not to criticize English antirealists' disbelief of T. English antirealists also concede too much to English realists, saying that the English realists' belief of $\mathrm{T}$ is within the bounds of reason. So English antirealists ought not to criticize it. Thus, English realists and antirealists ought not to criticize each other's stances. It is not surprising, then, that there has been no debate between English realists and antirealists in the literature ever since van Fraassen introduced the English conception of rationality in 1989.

English realism as depicted above exemplifies epistemic reciprocalism. It holds "that we ought to treat our epistemic colleagues, as they treat their epistemic colleagues" (Park, 2017a: 57). In accordance with epistemic reciprocalism, English realists treat English antirealists, as English antirealists treat their epistemic colleagues. 
English realism also exemplifies the epistemic imperative. It holds that "Act only on an epistemic maxim through which you can at the same time will that it should become a universal one" (Park, 2018a: 7). The epistemic imperative implies that English antirealists can act on the English conception of rationality, provided that they can will that the English conception of rationality should become a universal one. The English conception of rationality would become a universal one, if all epistemic agents, including realists, acted on it. Realists would act on it to adhere to the belief of $\mathrm{T}$, just as antirealists would act on it to adhere to the disbelief of T. It would be a double standard for antirealists to say that they are entitled to use the English conception of rationality to defend their stance whereas realists are not.

English realists differ significantly from Papineau (1996) and Musgrave (2017). English realists are armed, while Papineau and Musgrave are not, with the English conception of rationality, so English realists affirm, while Papineau and Musgrave deny, that the disbelief of $\mathrm{T}$ is reasonable. As a result, the two camps respond differently to van Fraassen. English realists do not criticize van Fraassen's disbelief of T. By contrast, Papineau and Musgrave criticize van Fraassen's disbelief of T. Musgrave, for example, argues that "truth explains empirical adequacy better than empirical adequacy does, because the latter 'explanation' is completely circular" (2017: 87). His point is that it is not circular to suggest that $\mathrm{T}$ is empirically adequate because $\mathrm{T}$ is true, but it is circular to suggest that $\mathrm{T}$ is empirically adequate because observables operate as if $\mathrm{T}$ were true. So the belief of $\mathrm{T}$ is reasonable whereas the disbelief of $\mathrm{T}$ is unreasonable. Van Fraassen replies that Musgrave does not say anything about "what explanation is good for, or what purposes it may serve" (2017: 101). Van Fraassen cannot raise such an objection to English realists.

Musgrave might argue that since the truth of $\mathrm{T}$ explains the empirical adequacy of $\mathrm{T}$ whereas the behavior of observables cannot explain the empirical adequacy of $\mathrm{T}$, the belief of $\mathrm{T}$ is reasonable whereas the disbelief of $\mathrm{T}$ is unreasonable. It follows that his argument refutes van Fraassen's view that the disbelief of T is reasonable. ${ }^{3}$

Van Fraassen would accept Musgrave's foregoing possible objection, if he chose the Prussian conception of rationality over the English conception of rationality. He, however, chooses the latter over the former, so he would reply that since abduction is epistemically inert, the disbelief of $\mathrm{T}$ is reasonable despite Musgrave's foregoing possible objection. In other words, the explanation of the empirical adequacy of $\mathrm{T}$ in terms of the truth of $\mathrm{T}$ does not have the force to make the belief of $\mathrm{T}$ rationally compelling. Under the condition that the belief of $\mathrm{T}$ is not rationally compelling, the English conception of rationality implies that the disbelief of $\mathrm{T}$ is rationally permissible.

Let me now turn to a possible objection from van Fraassen. He might object that English realism is an incoherent position. How can realists say that the disbelief of $\mathrm{T}$ is reasonable? If they say so, they are not realists but rather antirealists.

My rejoinder to this objection is that it applies no less to English antirealists, as the preceding imaginary dialogue shows. How can antirealists say that the belief of $\mathrm{T}$ is reasonable? If they say so, they are not antirealists but rather realists. Just as van Fraassen claims that the English conception of rationality allows for antirealists to say that the belief of $\mathrm{T}$ is reasonable, so I claim that the English conception of rationality allows for realists to say that the disbelief of $\mathrm{T}$ is reasonable.

I claimed above that English realists and antirealists ought not to criticize each other's stances. Critics might object that it is not clear why seeing an opponent's belief as reasonable should prevent one from criticizing it. In fact, one could say that seeing the reasonableness of

\footnotetext{
${ }^{3}$ I thank a referee for this comment.
} 
an opponent's position is a prerequisite for (constructive) discussion and criticism, since it would be difficult to debate a position that one does not find rational. ${ }^{4}$

It is questionable, however, whether seeing the reasonableness of a position is a prerequisite for constructive criticism against it. Suppose, for example, that empiricists believe that $\mathrm{T}$ is empirically adequate on the grounds that it is successful. Pessimists observe that although theories such as Aristotelian mechanics and the Ptolemaic theory were successful, they were eventually overturned due to anomalies. On the basis of this observation, they construct the pessimistic induction that theories of the past were empirically inadequate, so theories of the present are also empirically inadequate (Lange, 2002: 282; Lyons, 2003: 898). In response, empiricists might retreat to the more modest position that $\mathrm{T}$ is approximately empirically adequate. In this debate, pessimists criticize the empiricists' old position not because they think that the old position is reasonable but rather because they think that the old position is unreasonable or at least falls short of being reasonable.

Critics might now say that although we believe that our opponents' position is reasonable, we can criticize our opponents' position so that our opponents modify it to a more reasonable position. So English realists can criticize English antirealists' disbelief of $T$ so that English antirealists modify it to a more reasonable stance, and English antirealists can criticize English realists' belief of $\mathrm{T}$ so that English realists modify it to a more reasonable stance.

This proposal, however, is problematic for the following two reasons. First, in general, if a position is reasonable, it is ipso facto beyond the call of rationality to modify it to a more reasonable position. Consequently, it is ipso facto gratuitous for English realists to criticize English antirealists' disbelief of $\mathrm{T}$ and for English antirealists to criticize English realists' belief of T.

Second, in general, when one criticizes a position that one takes to be reasonable, one should ensure that one's criticism is not severe enough to make the position unreasonable. If the criticism is too severe, it would refute one's own belief that the position is reasonable. In other words, it is incoherent for one to raise too severe of a criticism against a position that one takes to be reasonable. Therefore, when English realists and antirealists criticize each other's stances, they have the burden of showing that their criticisms are not severe enough to make each other's stances unreasonable.

I leave to English realists and antirealists the task of specifying exactly what criticisms they could raise against each other's stances. As mentioned earlier, there has been no debate between English realists and antirealists in the literature. We have no idea yet what criticisms they could raise against each other's stances and how the debate between them would unfold. Of course, van Fraassen has debates with many realists, such as Papineau and Musgrave, in the literature. Those realists, however, are not English realists (i.e., van Fraassen's invincible opponents) but rather Prussian realists, as will become clear in the next section.

\subsection{The Prussian Formulations}

In this section, I explicate what I call Prussian realism and Prussian antirealism, arguing that the advocates of the pessimistic induction and the no-miracles argument have operated under the Prussian conception of rationality.

The Prussian conception of rationality is built into both Prussian realism and Prussian antirealism. Prussian realists believe $\mathrm{T}$ and assert that the belief of $\mathrm{T}$ is reasonable while the disbelief of $\mathrm{T}$ is unreasonable. In contrast, Prussian antirealists disbelieve T and assert that the disbelief of $\mathrm{T}$ is reasonable while the belief of $\mathrm{T}$ is unreasonable.

\footnotetext{
${ }^{4}$ I am grateful to a referee for this objection.
} 
Are there Prussian realists in the literature? Musgrave is a Prussian realist. Recall that according to him, the belief of $\mathrm{T}$ can explain, but the behavior of observables cannot, why $\mathrm{T}$ is empirically adequate, so the belief of $\mathrm{T}$ is reasonable, but the disbelief of $\mathrm{T}$ is unreasonable. Jarrett Leplin is also a Prussian realist. He claims that generalizations "do not explain their instances" (1997: 23). For example, to say that some swans are white because all swans are is not to explain why some swans are white. Analogously, to explain success in term of empirical adequacy is not to explain success. Note that Leplin criticizes the belief that $\mathrm{T}$ is empirically adequate. If he were an English realist, he would not do it for the reasons stated above, e.g., criticizing the disbelief of T comes with the burden of showing that the criticism is not severe enough to make the disbelief of $\mathrm{T}$ unreasonable.

Are there Prussian antirealists in the literature? Some philosophers take van Fraassen to be a Prussian antirealist. Recall that Papineau takes van Fraassen to claim that "we ought never to believe in the truth of any theory which goes beyond the observable phenomena" (1996: 8). As we have seen in Section 2, however, van Fraassen resists such an interpretation. So he is not a Prussian antirealist. K. Brad Wray seems to be a Prussian antirealist. Wray (2008: 321, 2012: 376) claims that $\mathrm{T}$ is merely empirically adequate, which implies that he disbelieves T. Wray (2013) defends the pessimistic induction, which indicates that he takes the belief of $\mathrm{T}$ to be unreasonable. If he were an English antirealist, he would not run the pessimistic induction against $\mathrm{T}$.

What are the similarities and differences between Prussian and English realists and between Prussian and English antirealists? The similarity between Prussian and English realists is that both realists believe $\mathrm{T}$. The difference between them is that Prussian realists deny, while English realists affirm, that the disbelief of $\mathrm{T}$ is reasonable. The similarity between Prussian and English antirealists is that both antirealists disbelieve T. The difference between them is that Prussian antirealists deny, while English antirealists affirm, that the belief of $\mathrm{T}$ is reasonable.

There is another important difference between English realists and Prussian realists. English realists are van Fraassen's invincible opponents, whereas Prussian realists are not. English realists share with van Fraassen the view that the disbelief of $\mathrm{T}$ is reasonable, whereas Prussian realists do not. So it is incoherent for van Fraassen to challenge English realists to prove that the disbelief of $\mathrm{T}$ is unreasonable, though it is coherent for him to challenge Prussian realists to prove this.

Let me turn to the issue of how the Prussian conception of rationality is related to the pessimistic induction and the no-miracles argument. These two arguments have dominated the realism debate since the 1970s (Worrall, 1989; Psillos, 1996; Sankey, 2017). In my view, the Prussian conception of rationality is built into them, and the advocates of them have operated under the Prussian conception of rationality. Let me flesh out this claim.

The no-miracles argument (Putnam, 1975: 73) holds, roughly, that there are two competing hypotheses explaining why science is successful. One is that "successful theories are mostly (approximately) true, and that no miracle has occurred" (Park, 2019b: 2). The other is that "successful theories are mostly (completely) false, and that a miracle has occurred" (Park, 2019b: 2). It is reasonable to believe that a miracle did not occur, but unreasonable to believe that a miracle occurred. It follows that the belief of $\mathrm{T}$ is reasonable whereas the disbelief of $\mathrm{T}$ is unreasonable. Note that the no-miracles argument does not say that both the belief and the disbelief of $\mathrm{T}$ are reasonable.

The pessimistic induction holds that "reflection on the abandonment of theories in the history of science motivates the expectation that our best current theories will themselves be abandoned, and hence that we ought not to assent to them" (Ladyman, 2014). To say that we ought not to assent to our best current theories means that the belief of them is unreasonable. 
Thus, the pessimistic induction comes down to the inference that since the belief of our best past theories was unreasonable, the belief of our best present theories is unreasonable. Realists have mounted several criticisms against the pessimistic induction (Park, 2018b: 11). Neither pessimists nor realists, however, claim that the criticisms show that the pessimistic induction is not rationally compelling, so both the belief and the disbelief of our best theories are reasonable.

\section{Wide vs. Narrow Formulations}

In Subsection 3.1 and Subsection 3.2, I expounded upon the English and Prussian formulations of realism and antirealism, respectively. In this section, I attempt to establish that the Prussian formulations are better than the English formulations.

Let me first distinguish between wide and narrow formulations of rivaling positions. In the wide formulations, there is a wide gap between the formulations of rivaling positions, whereas in the narrow formulations, there is a narrow gap between the formulations of rivaling positions. The more that rivaling positions make conflicting claims, the wider the gap between them; the more that rivaling positions make the same claims, the narrower the gap between them. What is the philosophical significance of the wide and narrow gaps? The wider the gap, the more rivaling interlocutors disagree, and the narrower the gap, the more rivaling interlocutors agree. Thus, there can be more debates between the interlocutors in the former case than in the latter case.

An example would be useful for illustrating the distinction between narrow and wide formulations. There is a wide gap between pessimism (Stanford, 2006) and realism (Putnam, 1975: 73), whereas there is a narrow gap between pessimism and selectivism (Kitcher, 1993: Chapters 4 and 5). Pessimism holds that "we are in the midst of an ongoing historical process in which our theoretical conceptions of nature will continue to change just as profoundly and fundamentally as they have in the past" (Stanford, 2015: 875). On this account, 'approximately true' is not attributable to successful theories. By contrast, realism (Putnam, 1975: 73) holds that we are no longer in the aforementioned historical process, and 'approximately true' is attributable to successful current theories. Selectivism sits somewhere between pessimism and realism (Park, 2019b: 7). It holds that we are in the historical process but that some theoretical constituents of successful theories will be preserved in their successors as well as that 'approximately true' is attributable to successful theories. Note that pessimism and selectivism share the view that we are in the historical process, but they diverge on the issue of whether 'approximately true' is attributable to successful theories. It is for this reason that Stanford claims that the difference between pessimism and selectivism is "simply a difference of style or taste in applying the expression 'approximately true' rather than a substantive disagreement between them" (2015: 875). By contrast, pessimism and realism diverge both on the issue of whether we are in the historical process and on the issue of whether 'approximately true' is attributable to successful current theories. It follows that the gap between pessimism and realism is wider than that between pessimism and selectivism.

The Prussian formulations of realism and antirealism are wide. Recall that Prussian realists believe $\mathrm{T}$ and assert that the belief of $\mathrm{T}$ is reasonable whereas the disbelief of $\mathrm{T}$ is unreasonable. By contrast, Prussian antirealists disbelieve T and assert that the disbelief of T is reasonable whereas the belief of $\mathrm{T}$ is unreasonable. Prussian realists and antirealists make different choices between the belief and the disbelief of T. In addition, they disagree on the issue of whether the belief of $\mathrm{T}$ is reasonable as well as on the issue of whether the disbelief of $\mathrm{T}$ is reasonable. The gap between Prussian realists and antirealists is so wide that they can have debates with each other. 
In contrast, the English formulations of realism and antirealism are narrow. Recall that English realists believe $\mathrm{T}$ and assert that both the belief and the disbelief of $\mathrm{T}$ are reasonable. English antirealists disbelieve $\mathrm{T}$ and assert that both the belief and the disbelief of $\mathrm{T}$ are reasonable. English realists and antirealists make different choices about the belief and the disbelief of T. They agree, however, on the issue of whether the belief of $\mathrm{T}$ is reasonable as well as on the issue of whether the disbelief of $\mathrm{T}$ is reasonable. The gap between English realists and antirealists is so narrow that they cannot have any debate with each other.

The Prussian and English formulations of realism and antirealism compete with each other. Which formulations should realists and antirealists choose? In general, formulations of opposing positions are proposals for how to use certain terms. So they can neither be true nor be false. They can only be useful or useless. As we have seen above, the Prussian formulations are so wide that Prussian realists and antirealists can have debates, whereas the English formulations are so narrow that English realists and antirealists cannot have any debate. We can learn about science through debates. Consequently, the Prussian formulations are more useful than the English formulations.

Stanford (2018) would accept my foregoing argument for the Prussian formulations. He proposes that we stop debating whether 'approximately true' is attributable to successful theories, and that we instead start debating whether there will be scientific revolutions. On his account, where there is only a terminological difference between opposing positions, there is not much room for debate between opposing discussants. By contrast, where there is a substantive difference in addition to the terminological difference between opposing positions, there is much room for debate. Thus, he strives for wide formulations of rivaling positions on the grounds that they can generate debates.

My foregoing argument for the Prussian conception of rationality differs from the controversial argument that realists and antirealists should choose the Prussian conception of rationality over the English conception of rationality because the former is right or true whereas the latter is wrong or false. This argument requires an explication of what it means to say that a conception of rationality is right, true, wrong, or false, let alone proof that the positive predicates are attributable to the Prussian conception of rationality, while the negative predicates are attributable to the English conception of rationality.

As noted in Subsection 3.2, many philosophers think that the pessimistic induction and the no-miracles argument hold the central place in the realism debate. What made these two arguments so influential? My answer to this question is that the Prussian conception of rationality is built into them. It made the gap between realism and antirealism wide, creating significant room for debates between realists and antirealists.

In Subsection 3.2, I claimed that English realists are van Fraassen's invincible opponents. This claim can be understood in light of the notions of narrow and wide formulations. Van Fraassen cannot defeat English realists not because they have strong arguments for English realism but rather because they are more like van Fraassen's allies than foes, i.e., because the gap between English realism and antirealism is so narrow. Van Fraassen's refutation of English realism would be almost like a refutation of his own position, English antirealism. The other side of the coin is that van Fraassen's position is invincible to English realists not because he has strong arguments for English antirealism ${ }^{5}$ but rather because he is more like their ally than foe. English realists' refutation of van Fraassen's position would be almost like a refutation of their own position, English realism. In short, van Fraassen's position cannot be defeated by English realists not because it is fortified by strong arguments but rather because it is too close to English realism.

\footnotetext{
5 As Park (2017b: 26-27) observes, van Fraassen does not even attempt to prove that the English conception of rationality is better than the Prussian conception of rationality.
} 


\section{Objections and Replies}

Objectors might say that the narrower the gap between rivaling positions, the more common ground between them, and thus, the more there can be cooperation between them. The cooperation can lead to an "analysis of the criteria and norms that are in force in scientific practice, and through these an understanding of what that practice is, and of the place it can have in a rational appreciation of ourselves in our world" (van Fraassen, 2017: 107). Hence, the English formulations of realism and antirealism are better than the Prussian formulations of realism and antirealism. ${ }^{6}$

Let me make two critical comments on this cooperation issue. First, admittedly, English realists and antirealists can cooperate with each other in the enterprise of analyzing and understanding science. Prussian realists and antirealists, however, can also cooperate with each other in the same enterprise. Having different views about whether the belief and the disbelief of $\mathrm{T}$ are reasonable does not mean that they cannot cooperate with each other in the enterprise of analyzing and understanding science. In other words, the wide formulations of realism and antirealism are compatible with the kind of cooperation that van Fraassen has in mind. In addition, a debate is a form of cooperation between rivaling debaters in the attempt to learn something. Prussian realists and antirealists can have a debate with each other over whether the belief and the disbelief of $\mathrm{T}$ are reasonable, while English realists and antirealists cannot. So the Prussian formulations can generate more cooperation than the English formulations.

Second, English realists and antirealists can cooperate with each other not only in the enterprise of analyzing and understanding science but also in the debate with Prussian realists and antirealists. English realists and antirealists assert that the belief of $\mathrm{T}$ is reasonable whereas Prussian antirealists assert that the belief of $\mathrm{T}$ is unreasonable. So English realists and antirealists can form an alliance against Prussian antirealists. In addition, both English realists and antirealists assert that the disbelief of $\mathrm{T}$ is reasonable, whereas Prussian realists assert that the disbelief of $\mathrm{T}$ is unreasonable. So English realists and antirealists can form an alliance against Prussian realists. This cooperation between English realists and antirealists, however, only reinforces my conviction that the gap between them is so narrow that they are allies rather than foes and they cannot have a debate with each other.

Let me turn to another objection. Objectors might say that given that to disbelieve $\mathrm{T}$ is to be skeptical about T, it is not clear what it means for me to say that "English realists use it to cling to the belief of T, whereas English antirealists use it to cling to the disbelief of T." This sentence presupposes that the disbelief of $\mathrm{T}$ needs to be established or argued for. In general, however, a skeptical stance does not need to be established or argued for. ${ }^{7}$

I agree with the reviewer that the disbelief of $\mathrm{T}$ is a skeptical stance, and that to disbelieve $\mathrm{T}$ is not to believe $\mathrm{T}$. I disagree with the reviewer, however, on whether the skeptical stance needs to be established or not. If it does not need to be established, it is not clear why van Fraassen uses the English conception of rationality to argue that the disbelief of $\mathrm{T}$ is reasonable. He might as well state, "I disbelieve $\mathrm{T}$ " without invoking the English conception of rationality. Thus, unlike the reviewer, van Fraassen thinks that the disbelief of T needs to be established, although it is a skeptical stance.

Moreover, Park (2019c) argues that the disbelief of T has many epistemic and practical disadvantages. Let me introduce just one epistemic disadvantage and one practical disadvantage here. If you disbelieve your epistemic colleagues' positive theories, they will, in return, disbelieve your positive theories, and hence you will not able to achieve the epistemic

\footnotetext{
6 I am grateful to a referee for this objection.

7 I am grateful to a reviewer for this comment.
} 
goal of spreading the truth of your positive theories to your epistemic colleagues. Moreover, if your epistemic colleagues disbelieve your positive theories, you will be denied the chance to receive a scholarly award from an award committee, for the committee members will reject your application on the grounds that they disbelieve your positive theories. It follows that those who merely say, "I disbelieve T!" need to establish that the advantages of disbelieving $\mathrm{T}$ outweigh the disadvantages of disbelieving $\mathrm{T}$.

\section{Conclusion}

English realists and antirealists ought not to criticize each other. English realists believe T and assert that both the belief and the disbelief of $\mathrm{T}$ are reasonable. In contrast, English antirealists disbelieve $\mathrm{T}$ and assert that both the belief and the disbelief of $\mathrm{T}$ are reasonable. Given that English realists and antirealists agree that both the belief and the disbelief of $\mathrm{T}$ are reasonable, English realists ought not to criticize English antirealists' disbelief of T, and English antirealists ought not to criticize English realists' belief of T.

By contrast, Prussian realists and antirealists ought to criticize each other. Prussian realists believe $\mathrm{T}$ and assert that the belief of $\mathrm{T}$ is reasonable. Prussian antirealists do not agree that the belief of $\mathrm{T}$ is reasonable. Hence, Prussian antirealists ought to criticize the belief of T. Prussian antirealists disbelieve $\mathrm{T}$ and assert that the disbelief of $\mathrm{T}$ is reasonable. Prussian realists do not agree that the disbelief of $\mathrm{T}$ is reasonable. Hence, Prussian realists ought to criticize the disbelief of $\mathrm{T}$.

As this summary indicates, the gap between English realism and antirealism is so narrow that there cannot be a debate between English realists and antirealists, whereas the gap between Prussian realism and antirealism is so wide that there can be debates between Prussian realists and antirealists. We can learn about science through debates. Therefore, realists and antirealists should choose the Prussian formulations over the English formulations as the framework of their debate. Let me end this paper with a motto: "Wide formulations are more productive than narrow ones."

\section{References}

Kitcher, Philip (1993). The Advancement of Science: Science without Legend, Objectivity without Illusion. New York: Oxford University Press.

Ladyman, James (2014). "Structural Realism", The Stanford Encyclopedia of Philosophy. Edward N. Zalta (ed.), URL = <https://plato.stanford.edu/archives/win2016/entries/structuralrealism/>.

Lange, Marc (2002). "Baseball, Pessimistic Inductions and the Turnover Fallacy", Analysis 62 (4): 2881-2885.

Leplin, Jarrett (1997). A Novel Defense of Scientific Realism. New York: Oxford University Press.

Lyons, Timothy (2003). "Explaining the Success of a Scientific Theory", Philosophy of Science 70 (5): 891-901.

Musgrave, Alan (2017). "Strict Empiricism Versus Explanation in Science", In Evandro Agazzi (ed.), Varieties of Scientific Realism: Objectivity and Truth in Science. Switzerland: Springer International Publishing, 71-93. 
Papineau, David (1996). The Philosophy of Science. Oxford: Oxford University Press.

Park, Seungbae (2017a). "Defense of Epistemic Reciprocalism”, Filosofija. Sociologija 28 (1): 56-64. 16 (1): $23-37$.

(2017b). "Scientific Antirealists Have Set Fire to Their Own Houses", Prolegomena (2018a). "In Defense of the Epistemic Imperative", Axiomathes 28 (4): 435-446.

(2018b). "The Grand Pessimistic Induction", Review of Contemporary Philosophy 17: 7-19.

(2019a). "How to Overcome Antirealist Objections to Scientific Realism", Axiomathes (to be determined). DOI: 10.1007/s10516-019-09432-3.

(2019b). "In Defense of Realism and Selectivism from Lyons's Objections", Foundations of Science (to be determined). DOI: 10.1007/s10699-019-09614-7.

(2019c). "The Disastrous Implications of the 'English' View of Rationality in a Social World”, Social Epistemology 33 (1): 88-99.

Psillos, Stathis (1996). "Scientific Realism and the "Pessimistic Induction", Philosophy of Science 63 (Proceedings): S306-S314.

Putnam, Hilary (1975). Mathematics, Matter and Method (Philosophical Papers, vo. 1), Cambridge: Cambridge University Press.

Sankey, Howard (2017). "Realism, Progress and the Historical Turn", Foundations of Science 22 (1): 201-214.

Stanford, P. Kyle (2006). Exceeding Our Grasp: Science, History, and the Problem of Unconceived Alternatives. Oxford: Oxford University Press.

(2015). "Catastrophism, Uniformitarianism, and a Scientific Realism Debate That Makes a Difference", Philosophy of Science 82 (5): 867-878.

(2018) “A Fond Farewell to 'Approximate Truth'?” Spontaneous Generations: A Journal for the History and Philosophy of Science 9 (1): 78-81.

van Fraassen, Bas (1989). Laws and Symmetry. Oxford: Oxford University Press.

------- (2007). "Reply: From a View of Science to a New Empiricism", In Bradley Monton (ed.), Images of Empiricism: Essays on Science and Stances, with a Reply from Bas van Fraassen. Oxford: Oxford University Press, 337-383.

(2017). "Misdirection and Misconception in the Scientific Realism Debates", In Evandro Agazzi (ed.), Varieties of Scientific Realism: Objectivity and Truth in Science. Switzerland: Springer International Publishing, 95-108. 
Worrall, John (1989). "Structural Realism: The Best of Both Worlds", Dialectica 43: 99-124.

Wray, K. Brad (2008). "The Argument from Underconsideration as Grounds for Anti-Realism: A Defence", International Studies in the Philosophy of Science 22 (3): 317-326.

(2012). "Epistemic Privilege and the Success of Science”, Nô̂s 46 (3): 375-385.

--------- (2013). "The Pessimistic Induction and the Exponential Growth of Science Reassessed", Synthese 190 (18): 4321-4330. 